\title{
Patient satisfaction with orthodontic treatment and its impact on daily routines with regard to age, gender and social status: a contemporary survey
}

\section{Satysfakcja z leczenia ortodontycznego i jego wpływ na codzienne funkcjonowanie pacjentów z uwzględnieniem wieku, płci i pozycji społecznej-badanie ankietowe}

\author{
Magdalena Homaj ${ }^{1}$, Zbigniew Siudak ${ }^{2}$ \\ ${ }^{1}$ Private Dental Practice "Stomatologia Beliny", Krakow, Poland \\ 2Department of Internal Medicine, Collegium Medicum, Jan Kochanowski University, Kielce, Poland \\ Head of the Department: Prof. Zbigniew Siudak MD, PhD
}

Key words: patients, satisfaction, orthodontics.

Słowa kluczowe: pacjenci, satysfakcja, ortodoncja.

\begin{abstract}
Introduction: The majority of contemporary studies suggest that there is almost unanimous satisfaction with and acceptance of orthodontic treatment among patients. In some studies pain is suggested as a predominant feature that influences patient's perception of the treatment as a whole.

Aim of the research: To find predictors of pain and impairment of daily routines in patients currently undergoing orthodontic treatment.

Material and methods: The study was based on a self-created anonymous questionnaire with both close-ended and open questions. Patients from one dental practice were asked to fill out anonymous questionnaire on satisfaction with orthodontic treatment and its impact on their daily routines.

Results: There were altogether 148 questionnaires filled out by 108 (73\%) women and 40 (27\%) men. Mean age of patients was $25.8 \pm 6.4$ (min.-max.: 18-44) years. The mean length of orthodontic treatment was $12.2 \pm 8.4$ months (min.-max.: 1-36). Majority of patients (98\%) were satisfied with their orthodontic treatment (grades 4 and 5). Pain was present mostly during application of braces (81\%) and in half of patients during control visits (48\%) and was never reported as a continuous feature. Younger patients $(<25$ years of age) tended to feel pain more often when applying braces. Patients with longer treatment time (at least 12 months after applying braces) tended to report significantly $(p<0.05)$ less inconveniences caused by braces during eating than those with shorter treatment.

Conclusions: Majority of patients were satisfied with treatment. Orthodontists should pay attention to pain management during application of braces in younger patients and provide patients with adequate information on possible impairment of daily routines during the treatment.
\end{abstract}

\begin{abstract}
Streszczenie
Wprowadzenie: Większość współczesnych badań sugeruje, że wśród pacjentów panuje niemal jednogłośna akceptacja leczenia ortodontycznego i satysfakcja. W niektórych badaniach sugeruje się, że ból jest dominującą cechą wpływającą na postrzeganie leczenia jako całości przez pacjenta.

Cel pracy: Ocena predyktorów bólu i upośledzenia codziennych czynności życiowych u pacjentów poddawanych leczeniu ortodontycznemu.

Materiał i metody: Badanie opierało się na samodzielnie stworzonym, anonimowym kwestionariuszu z pytaniami zamkniętymi i otwartymi. Pacjenci z jednego gabinetu stomatologicznego zostali poproszeni o wypełnienie anonimowej ankiety dotyczącej satysfakcji z leczenia ortodontycznego i jego wpływu na ich codzienne życie.

Wyniki: Łącznie przeprowadzono 148 ankiet, w których wzięło udział 108 (73\%) kobiet i 40 (27\%) mężczyzn. Średni wiek pacjentów wynosił 25,8 $\pm 6,4$ roku (min.-maks.: 18-44 lat). Średnia długość leczenia ortodontycznego wynosiła 12,2 $\pm 8,4$ miesiąca (min.-maks.: 1-36). Większość (98\%) pacjentów była zadowolona z leczenia ortodontycznego (stopień 4. i 5.). Ból występował głównie podczas zakładania aparatów ortodontycznych (81\%) oraz u połowy pacjentów podczas wizyt kontrolnych (48\%) i nigdy nie był zgłaszany jako cecha ciągła. Młodsi pacjenci (<25 lat) częściej odczuwali ból podczas zakładania aparatu. Pacjenci z dłuższym czasem leczenia (co najmniej 12 miesięcy po założeniu aparatu) zgłaszali istotnie $(p<0,05)$ mniej niedogodności związanych z aparatem podczas jedzenia niż pacjenci z krótszym czasem leczenia.

Wnioski: Większość pacjentów była zadowolona z leczenia ortodontycznego. Ortodonci powinni zwracać większą uwagę na leczenie bólu podczas zakładania aparatu ortodontycznego u osób młodych poniżej 25. roku życia i utrwalać pacjentom informacje na temat możliwych zaburzeń codziennych czynności podczas leczenia.
\end{abstract}




\section{Introduction}

The advances in orthodontics in the last decades are impressive and have changed the perception of orthodontic treatment for good. Orthodontic appliances have become more common and available for general public than ever before, even though the related costs are still relatively high in most countries. Having straight teeth is currently not only reserved for patients with congenital or acquired dental defects but namely for everyone who feels they should get orthodontic treatment and qualifies for it. The social well-being, peer- and self-acceptance play a major role when patients decide for orthodontic treatment. Applying braces in order to have straight teeth is not only an indicator of wealth or social status but also great care for health in general.

Orthodontic treatment with fixed appliances is a chronic burden for many years in majority of patients which often requires changes in lifestyle and habits. Therefore, understanding and addressing patients' needs by dentists throughout the process is crucial for achieving the final success and patients' satisfaction. It requires patience and mutual cooperation unlike in any other dental specialties.

Current literature often deals with patient perception of and satisfaction with orthodontic treatment in the setting of orthognathic surgery or cleft repair, which are specific and limited cohorts of orthodontic patients [1, 2]. However, it seems that physical appearance in terms of orthodontic issues is crucial especially for younger patients who often seek professional help to improve their appearance even in the absence of congenital or acquired defects $[3,4]$. There are not enough data to draw conclusions as for the long-term patient satisfaction with orthodontic treatment, mainly due to various nature of mostly observational studies $[5,6]$. It seems though that there is a strong relationship between dentist-staff-patient interactions. Dissatisfaction with orthodontic treatment is rare but often associated with the duration of treatment, levels of pain and discomfort [7]. Nevertheless, majority of contemporary studies suggest that there is almost a unanimous satisfaction and acceptance of orthodontic treatment among patients and variables like age and gender may also play a role in the level of satisfaction [8-13]. It has been reported that novel treatment methods (e.g. Invisalign ${ }^{\circledR}$ ) may provide better patient satisfaction [7, 14-18]. In some studies pain is suggested as a predominant feature of the success of patient perception of the orthodontic treatment as a whole [18]. Eating and fear of potential problems that fixed braces may cause during this everyday routine seems like an important issue for patients as well [16]. There are still limited data concerning the overall satisfaction with orthodontic treatment as well as its predictors. There are no current data from Poland addressing this issue.

\section{Aim of the research}

The main aim of the study was to assess the overall satisfaction of patients who are currently undergoing orthodontic treatment in a Polish out-patient dental private practice with a special focus on potential influence of age, gender, length of treatment and social status. Secondary aims included identification of the impact of orthodontic treatment on everyday life routines (eating, hygiene, speaking etc.) in this selected group of patients.

\section{Material and methods}

The study was based on a self-created questionnaire with both close-ended and open questions created by Magdalena Homaj. Patients received one-sided A4 print-outs and were asked to fill out the questionnaire. No time restrictions were imposed. Patients provided oral and written consent to take part in this study. The Local Ethics Committee approval was waived due to the voluntary status of the study participants which in no way affected treatment and no personal data were stored which could in any way identify each patient. The study was performed in line with the Declaration of Helsinki and its further amendments. No external funding was used to perform the study.

Anonymous questionnaires were collected between April and May 2021 in an out-patient private dental practice in Krakow, Poland during previously scheduled control visits. All consecutive patients who were asked, agreed to fill out the questionnaire. Predominant indications for orthodontic treatment included crowding of teeth and jaw narrowing. Retention treatment was applied or was planned in all patients for approx. 3-5 years with notable exceptions.

There were inclusion and exclusion criteria defined as below:

Inclusion criteria:

- Patient voluntary agreement to fill out the questionnaire,

- Orthodontic treatment lasting at least 1 month after applying braces,

- Age over 18 years,

- Fixed appliances.

Exclusion criteria:

- Prior orthodontic treatment in the past,

- Mental illness or incapacitation,

- Prior dental extraction due to orthodontic treatment.

\section{Statistical analysis}

Data were analyzed according to established statistical standards. Categorical variables were presented with counts and as percentages (\%) and continuous variables as means (with standard deviation). The equality of two or more continuous distributions was determined by the Kruskal-Wallis test. The indepen- 
dence of two categorical variables was determined by the $\chi^{2}$ test or in case of small counts by the Fisher exact test. A $p$-value of less than 0.05 was considered to be statistically significant. All data processing and statistical calculations were performed in Statistica 13.3 (Statsoft; Tulsa, OK).

\section{Results}

There were altogether 148 questionnaires filled out by patients during the enrolment period. There were $108(73 \%)$ women and $40(27 \%)$ men in the study. Mean age of patients was $25.8 \pm 6.4$ (min.-max.: $18-44)$ years. Majority of them (78\%) lived in larger (> 50000 inhabitants) cities, while $6 \%$ in small towns ( $<50000$ inhabitants) and the remaining 16\% in rural village areas. A higher degree of education (Bachelor/ Master or PhD - Doctor of Philosophy equivalent) was reported by $54 \%$ of them while $43 \%$ had the secondary level of education and 3\% had only completed primary education. The mean length of orthodontic treatment was $12.2 \pm 8.4$ months (min.-max.: 1-36). The overall satisfaction with orthodontic treatment was graded on a scale from 1 to 5 (defining " 5 " as the highest satisfaction level). Majority of patients (88.5\%) gave " 5 " points, whereas $9.5 \%$ gave " 4 ", $1.4 \%$ patients gave " 3 " points and $0.6 \%$ of patients gave " 2 ". All patients $(n=148)$ would decide again to undergo orthodontic treatment with all the knowledge that they have now about orthodontic treatment. There were no significant differences in satisfaction with orthodontic treatment ( 5 vs. $1+2+3+4$ ) with regard to age, gender, education level or place of living and the length of treatment $(p>0.05)$.

Participants reported pain mostly when braces were applied (81\%) and less frequently during con-
Table 1. Perception of pain by gender

\begin{tabular}{|lccc|}
\hline Variable & $\begin{array}{c}\text { Female } \\
\boldsymbol{N}=108\end{array}$ & $\begin{array}{c}\text { Male } \\
\boldsymbol{N}=\mathbf{4 0}\end{array}$ & $\boldsymbol{P}$-value \\
When applying braces & $83 \%$ & $75 \%$ & 0.25 \\
During control visits & $45 \%$ & $55 \%$ & 0.298 \\
Regardless of control visits & $9 \%$ & $10 \%$ & 0.891 \\
\hline
\end{tabular}

Table 2. Perception of pain by age

\begin{tabular}{|lccc|}
\hline Variable & $\begin{array}{c}25 \text { years } \\
\text { or less } \\
\boldsymbol{N}=\mathbf{7 4}\end{array}$ & $\begin{array}{c}\text { Over } \\
\mathbf{2 6} \text { years }\end{array}$ & $\boldsymbol{P}$-value \\
When applying braces & $88 \%$ & $74 \%$ & 0.036 \\
During control visits & $45 \%$ & $51 \%$ & 0.411 \\
Regardless of control visits & $11 \%$ & $8 \%$ & 0.574 \\
\hline
\end{tabular}

trol visits (48\%) or in between $(9.5 \%)$. No patient reported constant continuous pain. Perception of pain by gender and age is presented in Tables 1 and 2 . Data concerning patients' subjective assessment of impairment of various everyday routines by orthodontic treatment and presence of braces is presented in Figure 1 (" 5 " means severe impairment and " 1 " is defined as no impact on daily life). In Figure 2, we present subjective impairment of eating stratified by length of orthodontic treatment after applying braces $(p=0.003)$. No associations have been found for any daily routine stratified either by gender, place of living or education level. The last question of the questionnaire asked participants if orthodontic treatment changed their hygiene habits and as much as 132 of $148(89 \%)$ said "Yes". Of these in $98 \%$ of the cases it was a change "for better".

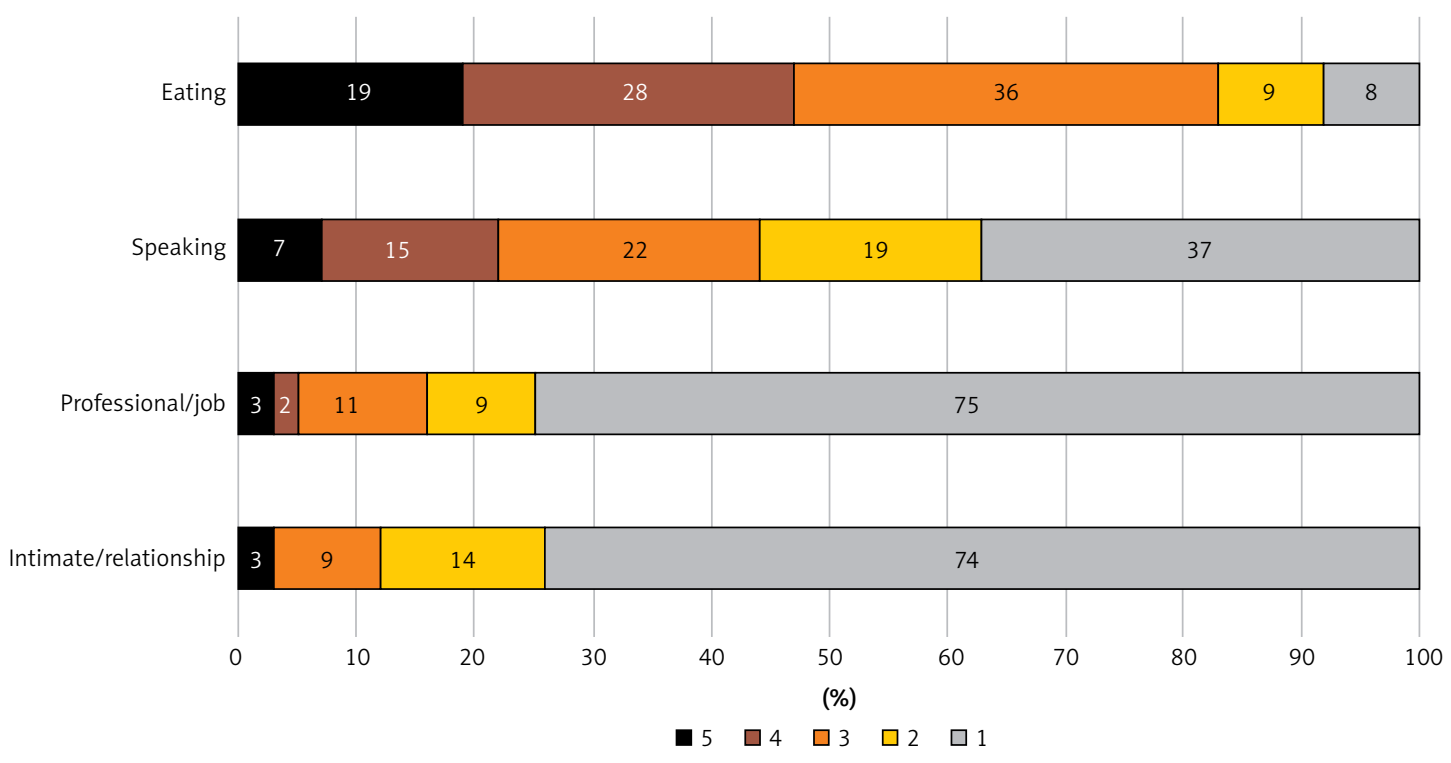

Figure 1. Impact of orthodontic treatment on daily routines - all patients 


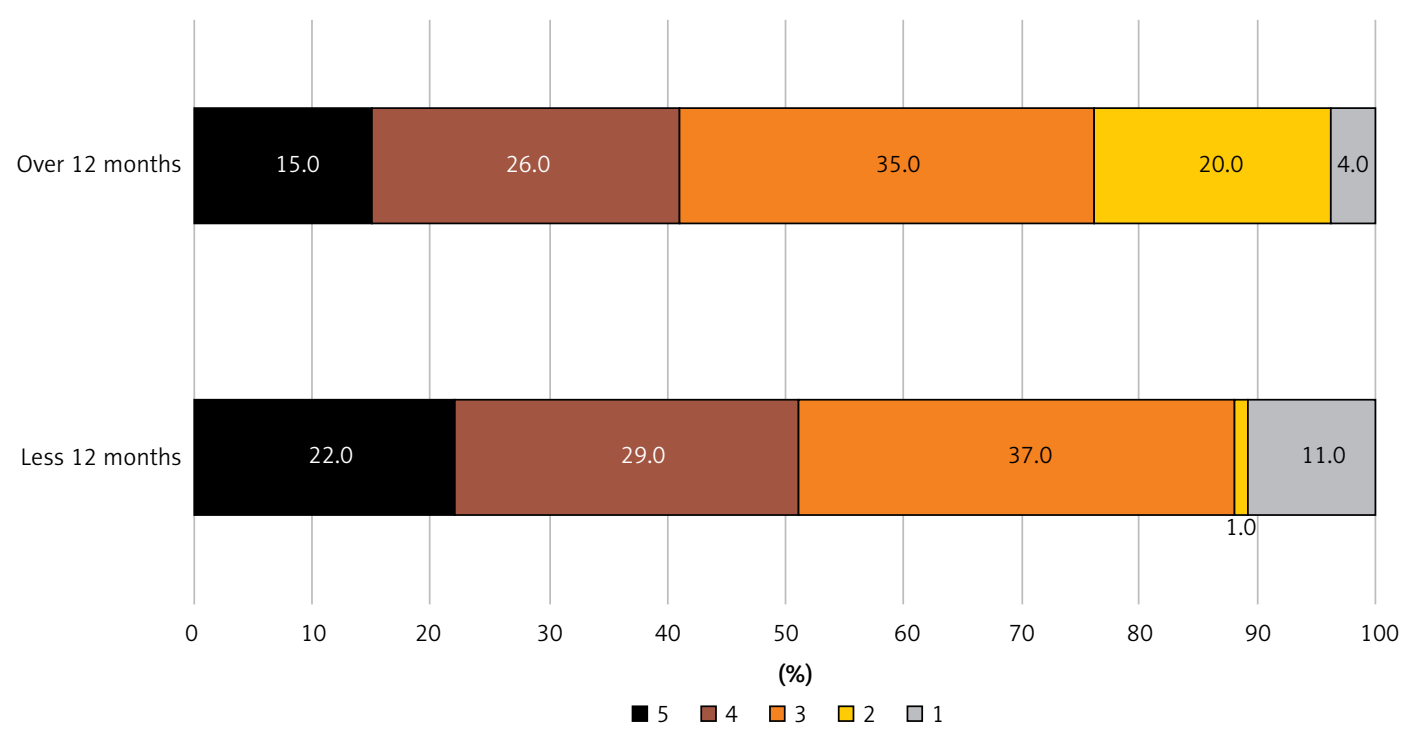

Figure 2. Impact of length of treatment on eating impairment in patients

\section{Discussion}

This study was the first contemporary attempt in Poland to assess patient satisfaction with orthodontic treatment and its impact on patients' everyday routines. Since it is a single-center and single-dentist experience it should not be extrapolated to the general population, however, it might stimulate larger, prospective, multicenter studies in Poland and worldwide.

The vast majority of patients in this study were satisfied with their orthodontic treatment even though pain was present when applying their braces in most cases and to some extent during control visits. These results are in line with previous reports where high levels of satisfaction have been reported [7-9, 12-16] and satisfaction and quality of life plays a crucial role in patient perception of the treatment $[16,19,20]$.

The only significant association found was between eating impairment which was more pronounced in patients with less than 12 months of treatment after fixing appliances. Nevertheless, there were also several relationships that were close to statistical significance $(p<0.1)$ and are worth mentioning. A trend towards more pronounced impairment of intimate relationship and professional work was seen among older patients $(>26)$ rather than younger ones. This might be correlated since these are the patients (26 and older) that usually begin their job careers and permanent relationships. Longer orthodontic treatment also tended to impair professional career.

This study has a number of limitations. The main one is a relatively small sample which allows to draw very basic and cautious conclusions. Additionally, no validated QoL (Quality of Life) questionnaire was conducted.

\section{Conclusions}

The majority of patients were satisfied with their orthodontic treatment and all would decide again to undergo this treatment had they known the consequences. Orthodontists should pay closer attention to pain management during application of braces especially in younger patients and underline possible impairment of daily routines like eating or speaking during their treatment.

\section{Conflict of interest}

The authors declare no conflict of interst.

\section{References}

1. Chen YH, Liao YF, Chang CS, Lu TC, Chen KT. Patient satisfaction and quality of life after orthodontic treatment for cleft lip and palate deformity. Clin Oral Investig 2021; 25: 5521-5529.

2. Pachêco-Pereira C, Abreu LG, Dick BD, De Luca Canto G, Paiva SM, Flores-Mir C. Patient satisfaction after orthodontic treatment combined with orthognathic surgery: a systematic review. Angle Orthod 2016; 86: 495-508.

3. Isiekwe GI, Aikins EA. Self-perception of dental appearance and aesthetics in a student population. Int Orthod 2019; 17: 506-512.

4. Alhaij MN, Ariffin Z, Celebić A, Alkheraif AA, Amran AG, Ismail IA. Perception of orofacial appearance among laypersons with diverse social and demographic status. PLoS One 2020; 15: e0239232.

5. Bondemark L, Holm AK, Hansen K, Axelsson S, Mohlin B, Brattstrom V, Paulin G, Pietila T. Long-term stability of orthodontic treatment and patient satisfaction. A systematic review. Angle Orthod 2007; 77: 181-191.

6. Yao J, Li DD, Yang YQ, McGrath CP, Mattheos N. What are patients' expectations of orthodontic treatment: a systematic review. BMC Oral Health 2016; 16: 19. 
7. Pachêco-Pereira C, Pereira JR, Dick BD, Perez A, Flores-Mir C. Factors associated with patient and parent satisfaction after orthodontic treatment: a systematic review. Am J Orthod Dentofacial Orthop 2015; 148: 652-659.

8. Keles F, Bos A. Satisfaction with orthodontic treatment. Angle Orthod 2013; 83: 507-511.

9. Lee R, Hwang S, Lim H, Cha JY, Kim KH, Chung CJ. Treatment satisfaction and its influencing factors among adult orthodontic patients. Am J Orthod Dentofacial Orthop 2018; 153: 808-817.

10. Feldmann I. Satisfaction with orthodontic treatment outcome. Angle Orthod 2014; 84: 581-587.

11. Wong L, Ryan FS, Christensen LR, Cunningham SJ. Factors influencing satisfaction with the process of orthodontic treatment in adult patients. Am J Orthod Dentofacial Orthop 2018; 153: 362-370.

12. Bradley E, Shelton A, Hodge T, Morris D, Bekker H, Fletcher S, Barber S. Patient-reported experience and outcomes from orthodontic treatment. J Orthod 2020; 47: 107-115.

13. Geoghegan F, Birjandi AA, Machado Xavier G, DiBiase AT. Motivation, expectations and understanding of patients and their parents seeking orthodontic treatment in specialist practice. J Orthod 2019; 46: 46-50.

14. Azaripour A, Weusmann J, Mahmoodi B, Peppas D, Gerhold-Ay A, Van Noorden CJ, Willershausen B. Braces versus Invisalign ${ }^{\circledR}$ : gingival parameters and patients’ satisfaction during treatment: a cross-sectional study. BMC Oral Health 2015; 15: 69

15. Alajmi S, Shaban A, Al-Azemi R. Comparison of short-term oral impacts experienced by patients treated with invisalign or conventional fixed orthodontic appliances. Med Princ Pract 2020; 29: 382-388.

16. Ohkubo M, Ueda T, Miura K, Sugito H, Ono K, Seshima F, Morioka T, Uchiyama S, Yoshida M, Yajima Y. "Easy-to-eat meals" for outpatients following dental treatment. Bull Tokyo Dent Coll 2019; 60: 225-232.

17. Pacheco-Pereira C, Brandelli J, Flores-Mir C. Patient satisfaction and quality of life changes after Invisalign treatment. Am J Orthod Dentofacial Orthop 2018; 153: 834-841.

18. Flores-Mir C, Brandelli J, Pacheco-Pereira C. Patient satisfaction and quality of life status after 2 treatment modalities: invisalign and conventional fixed appliances. Am J Orthod Dentofacial Orthop 2018; 154: 639-644.

19. Bialek KI, Sadowski M. The influence of selected factors on the degree of illness acceptance and on the level of satisfaction with life in patients hospitalised in cardiology departments. Medical Studies 2020; 36: 157-156.

20. Reszka K, Moskal $€$, Remiorz A et al. The prevalence of complementary and alternative methods and their impact on conventional cancer treatment among oncological patients in Poland - an institutional study. Medical Studies 2021; 37: 91-99.

\section{Address for correspondence:}

\section{Prof. Zbigniew Siudak}

Department of Internal Medicine

Collegium Medicum

Jan Kochanowski University

Kielce, Poland

Phone: +48883992288

E-mail: zbigniew.siudak@gmail.com

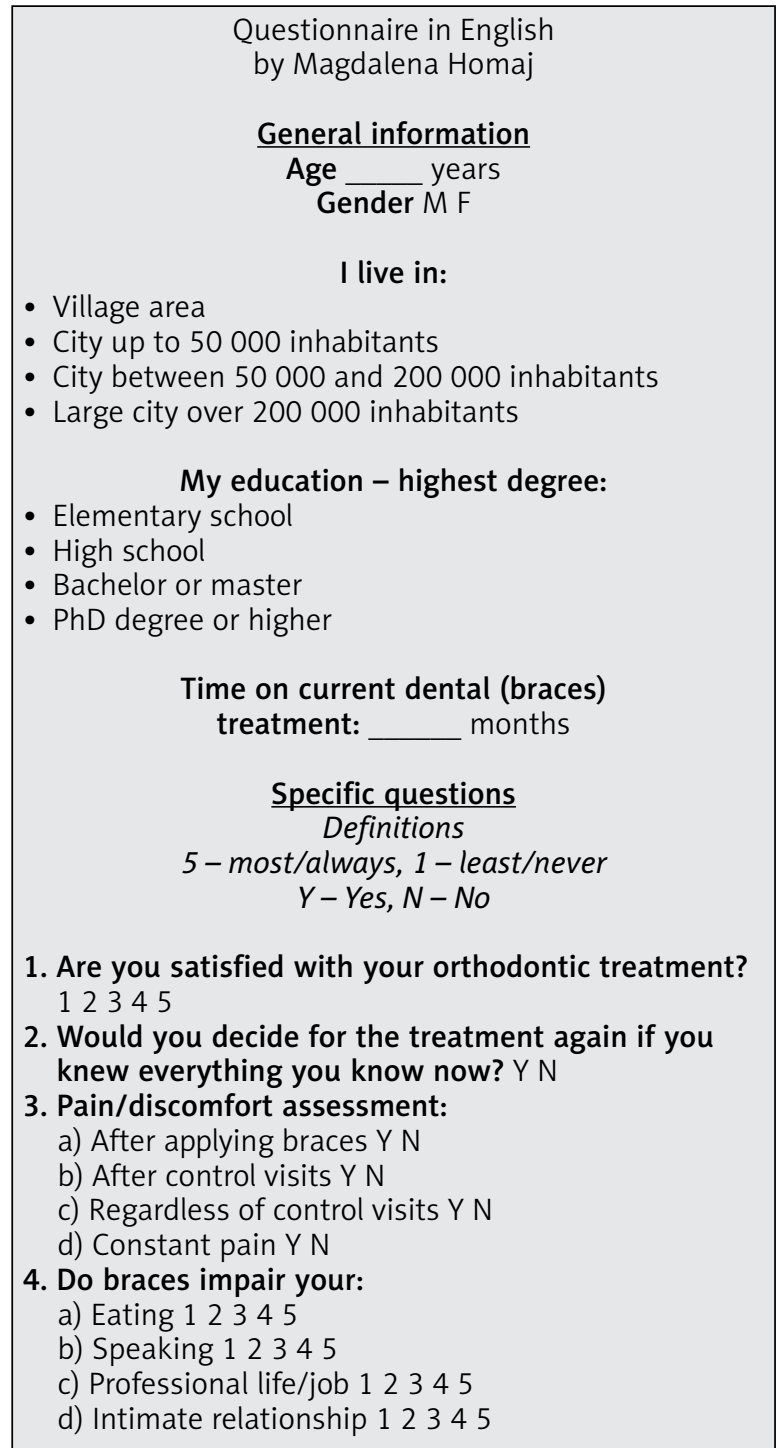

